\title{
Pore Characteristics and Adsorption Properties of Activated Carbon Produced from Ampelodismos Mauritanicus Stems
}

\author{
Amal Benhathat and Moussa Amrani* \\ Laboratory of Soft Technology, Recovering, \\ and Sustainable Development \\ M'Hamed Bougara University of Boumerdes \\ Boumerdes, Algeria
}

Received 06.03.2021, received in revised form 10.04.2021, accepted 03.06.2021

\begin{abstract}
In this paper, the synthesis and characterization of Ampelodesmos mauritanicus stems activated carbon (AMSAC) were studied. The produced activated carbon by phosphoric acid activation followed carbonisation was characterized by $N_{2}$ adsorption-desorption isotherm, scanning electron microscopy (SEM), energy-dispersive X-ray (EDX) analysis, and Fourier transform infrared (FTIR) spectroscopy. Sorption potential of AMSAC for the removal of methylene bleu from water was investigated. The experimental data found that AMSAC had high Brunauer-Emmett-Teller (BET) surface area of $1293 \mathrm{~m}^{2} / \mathrm{g}$ and abundant pores with specific volume of $1.23 \mathrm{~m}^{3} / \mathrm{g}$. FTIR analysis reveals various functional groups on the surface of AMSAC which can be play an important role for the adsorption process. Langmuir isotherm model fitted well the equilibrium data for the methylene bleu comparing to the Freundlich isotherm model; the monolayer sorption capacity of AMSAC was found to be $411.8 \mathrm{mg} / \mathrm{g}$ at $25^{\circ} \mathrm{C}$.
\end{abstract}

Keywords: active carbon, Ampelodesmos mauritanicus, chemical activation, physic-chemical carateristique, methylene bleu.

(C) Siberian Federal University. All rights reserved

This work is licensed under a Creative Commons Attribution-NonCommercial 4.0 International License (CC BY-NC 4.0).

* Corresponding author E-mail address: moussaamrani@yahoo.fr 


\title{
Характеристики пор и адсорбционные свойства \\ активированного угля, полученного \\ из стеблей Ampelodismos Mauritanicus
}

\author{
Амаль Бенхатат, Мусса Амрани \\ Лаборатория мягких технологий, \\ восстановления и устойчивого развития \\ Университет Бумердес имени Мхамеда Бугара \\ Алжир, Бумердес
}

\begin{abstract}
Аннотация. В данной работе были изучены синтез и характеристика активированного угля, полученного из стеблей Ampelodesmos mauritanicus (AMSAC). Активированный уголь, полученный путем активации фосфорной кислотой с последующей карбонизацией, охарактеризован изотермой адсорбции-десорбции $N_{2}$, сканирующей электронной микроскопией (SEM), энергодисперсионным рентгеновским анализом (EDX) и инфракрасной Фурьеспектроскопией (FTIR). Исследован сорбционный потенциал AMSAC для удаления из воды метиленового синего. Экспериментальные данные показали, что AMSAC имеет высокую площадь поверхности Брунауэра-Эммета-Теллера (BET) 1293 м²/г и обильные поры с удельным объемом 1,23 м³/г. Анализ FTIR выявляет различные функциональные группы на поверхности AMSAC, которые могут играть важную роль в процессе адсорбции. Модель изотермы Ленгмюра хорошо соответствовала равновесным данным для метиленового синего по сравнению с моделью изотермы Фрейндлиха; было установлено, что однослойная сорбционная емкость AMSAC составляет 411,8 мг/г при $25^{\circ} \mathrm{C}$.
\end{abstract}

Ключевые слова: активированный уголь, Ampelodesmos mauritanicus, химическая активация, физико-химическая характеристика, метиленовый синий.

Цитирование: Бенхатат, Амаль. Характеристики пор и адсорбционные свойства активированного угля, полученного из стеблей Ampelodismos Mauritanicus / Амаль Бенхатат, Мусса Амрани // Журн. Сиб. федер. ун-та. Химия, 2021, 14(2). C. 156-170. DOI: 10.17516/1998-2836-0225

\section{Introduction}

Activated carbon derived from lignocellulosic biomass is widely used for pollutant removal. Various industrial sectors use lignocellulosic activated carbon in operations such as chemical processes, petroleum refining, wastewater treatment, air pollution treatment and volatile organic compounds (VOC) adsorption [1-3]. In addition, activated carbon provides an effective mean for gas phase applications, such as for separation, deodorization, purification, storage and catalysis. Activated carbon is a well-known adsorbent due to its unique and versatile properties that allow the accessible of gas/liquid into internal pore surface and high degree of surface reactivity. However, in the recent years, the study of used annual plants as sources for activated carbons comes as result to the increasing demand for this adsorbent. These plants

$$
-157-
$$


are interesting because of their abundance, rapid growth and availablty in many regions of the world. Various studies on the production of activated carbon have been done by applying different biomass including cotton stalks [4], bamboo [5], Kenaf [6], sugar cane bagasse [7], wheat straw [8] sunflower stems [9].

Annually renewable plants, Ampelodesmos mauritanicus, can be also used as an alternative to wood for activated carbon production. This plant species belongs to the poaceae of the family Gramineae largely present in the Mediterranean area and in particular in North Africa. It grows both in wet and dry areas and it is abundantly available through the years which make it an important biomass. The average height of Ampelodesmos mauritanicus plant can exceed one meter and their fibers are extremely sturdy and rough [10-12]. Ampelodesmos mauritanicus main constituents with their weight proportions are cellulose (44.1\%), hemicelluloses $(27 \%)$, lignin (16.80\%), extractives (9\%), and ashes (3.1\%) [13].

The adsorptive properties of activated carbon depend on the nature of the precursor, the type of activation (chemical or physical) as well as on the processing conditions. It has been shown that in case of chemical activation, concentration of the dehydrating agent, impregnation ratio and pyrolysis temperature globally governs the properties of the resulting activated carbon [1]. Among the properties which characterize activated carbon, the more significant seem to be yield, content of volatiles, and fixed carbon content. Other important characteristics of activated carbon are the ash content, bulk density; hardness, active surface area, and adsorption efficiency towards iodine, phenol and methylene blue (MB) are frequently considered [14].

The aim of this work is to prepare activated carbon powder from Ampelodesmos mauritanicus stems using chemical activation with $\mathrm{H}_{3} \mathrm{PO}_{4}$ followed by carbonization in nitrogen atmosphere. Characterization of the activated carbon obtained in the optimal conditions was conducted, using the following techniques: Fourier transform infrared (FTIR) spectroscopy to determine the functional groups, Brunauer-Emmett-Teller (BET) to determine surface area and average pore size, scanning electron microscopy (SEM) to investigate the structure and morphology. In addition, adsorption iodine and the methylene bleu was used to examine the potential to absorb small and large molecules by AMSAC.

Characterization of the activated carbon obtained in the optimal conditions was conducted, using the following techniques: Fourier transform infrared (FTIR) spectroscopy to determine the functional groups, Brunauer-Emmett-Teller (BET) to determine surface area and average pore size, scanning electron microscopy (SEM) to investigate the structure and morphology. In addition, adsorption iodine and the methylene bleu for determine the potential to absorb small and large molecules by AMSAC were performed.

\section{Experimental}

\subsection{Raw material}

Ampelodesmos mauritanicus (Fig. 1) was collected from the north east of Boumerdes area, Algeria. This biomass material was harvested in early June 2016. The sample was washed with water to remove dirt, dried at $60^{\circ} \mathrm{C}$ for $8 \mathrm{~h}$ in an air oven and reduced to about $2 \mathrm{~cm}$ in length, with a razor blade, for effective milling to a size less than $500 \mu \mathrm{m}$. The residues after this milling were used for the compositional analysis and production of AMSAC. 


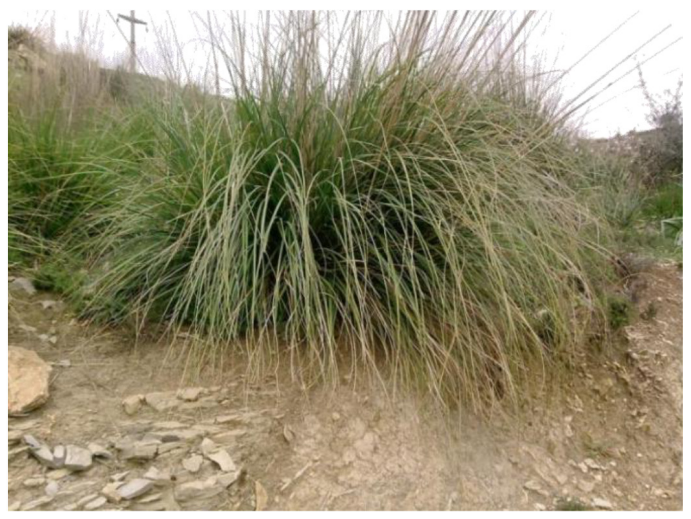

Fig. 1. Tuft of Ampelodesmos mauritanicus

\subsection{Activated carbon synthesis}

Ampelodesmos mauritanicus trunk powder was mixed well with ortho-phosphoric acid $\mathrm{H}_{3} \mathrm{PO}_{4}$ solutions (85\%) in weight ration 1:2 $\mathrm{g} / \mathrm{g}$ (ortho-phosphoric acid was purchased from MERCK Germany) at room temperature for $1 \mathrm{~h}$ and then dried in an oven (Memmert UNB 400) at $105^{\circ} \mathrm{C}$ for $24 \mathrm{~h}$. After the impregnation step, the sample was carbonized in a horizontal tube furnace (Nabertherm, Germany) under nitrogen atmosphere. The heating rate and the nitrogen flow rate were $5{ }^{\circ} \mathrm{C} / \mathrm{min}$ and $200 \mathrm{~mL} / \mathrm{min}$ respectively. The samples were kept at $500{ }^{\circ} \mathrm{C}$ for $2 \mathrm{~h}$. The crucibles were left inside the furnace for $24 \mathrm{~h}$ to cool down at room temperature. The prepared AMSAC samples were soaked in $0.1 \mathrm{~N} \mathrm{NaOH}$ for $2 \mathrm{~h}$, as the $\mathrm{pH}$ of the washing water reached to about 5, and then with two liters of hot de-ionized under reflux until the $\mathrm{pH}$ of the rinsing water was neutral. The samples were filtered through Whatman filter paper $(0.45 \mu \mathrm{m})$ to separate the supernatant and the AMSAC particles. After that, it was dried in hot air oven for $24 \mathrm{~h}$, weighed and packed in sealable plastic bags for further use.

\subsection{Activated carbon characterisation}

The surface structure of AMSAC was investigated with Scanning Electron Microscopy (SEM), a $N_{2}$ adsorption - desorption technique (BET method), FT-IR and X-ray diffraction (XRD). SEM was used to characterize the nano particles shape and size by FEI Quanta 650 scanner, with accelerating current of $80 \mu \mathrm{A}$ and voltage of $30 \mathrm{kV}$. SEM image was formed using transmitted electrons (instead of the visible light) which can produce magnification up to $1.00 .000 \mathrm{X}$ with resolution up to $100 \AA$. The Brunauer-Emmett-Teller (BET) surface area was measured by the $\mathrm{N}_{2}$ adsorption-desorption technique using Quanta Chrome Instruments Nova 2000E analyzer. The total pore volume was defined as the volume of liquid nitrogen corresponding to the amount adsorbed at a relative pressure of $P / P_{0}=0.99$. To calculate the pore size distribution of sample, the Barret- Joyner-Halenda (BJH) model was employed. The Fourier-transform infrared (FTIR) spectroscopy of the AMSAC was measured by a FTIR spectrometer Shimadzu $8400 \mathrm{~S}$, from 4000 to $400 \mathrm{~cm}^{-1}$. The measurement was carried out with a $\mathrm{KBr}$ pellet method $(0.5 \%$ of the sample in $\mathrm{KBr})$. The crystalline structure was analyzed by X-ray diffraction (XRD) using $\mathrm{Cu}-\mathrm{K} \alpha$ radiation (1.5418 $\AA$ ) of a Bruker D8 Advance diffractometer operating at $40 \mathrm{kV}, 40 \mathrm{~mA}$ for angles between $2 \theta=4-90^{\circ}$ in $0.02^{\circ}$ steps. The bulk density was determined according to procedure followed by Toshiguki and Yukata [15]. Moisture content was determined 
using oven drying method. Ash content was determined by standard method [16]. The adsorption properties of the activated carbons where characterized in terms of both iodine adsorption and MB adsorption indexes according to the procedure reported in the literature [17].

\subsection{Description test of $M B$ adsorption}

Equilibrium sorption studies were conducted in a set of $250 \mathrm{~mL}$ Erlenmeyer flasks containing $0.50 \mathrm{~g}$ AMSAC and $200 \mathrm{~mL} \mathrm{MB}\left(\mathrm{C}_{16} \mathrm{H}_{18} \mathrm{ClN}_{3} \mathrm{SCl}\right)$ (Fig. 2) solutions with various initial concentrations $(600,650,700,750,800,850$ and $900 \mathrm{mg} / \mathrm{L})$. The mixtures were oscillated at $120 \mathrm{r} / \mathrm{min}$ using a horizontal shaker (Edmund Buhler 7400 Tubingen, SM 25, Germany) continuously for 120 min, as the equilibrium time, at temperature of $25 \pm 1{ }^{\circ} \mathrm{C}$ and initial $p H=6$. After $120 \mathrm{~min}$, the suspension was filtered and the filtrate was analyzed for residual MB concentration using a Lambda 25 UV/VIS spectrophotometer (Perkin-Elmer, Germany) at $\lambda_{\max }$ of $665 \mathrm{~nm}$. The amount of MB uptake was calculated using Eq. (1):

$$
q_{e}=\left(C_{o}-C_{e}\right) \cdot V / M
$$

Where:

$q_{e}$ is the amount of BM adsorbed per unit mass of adsorbent $(\mathrm{mg} / \mathrm{g})$ at equilibrium time $\mathrm{t}$.

$C_{o}$ and $C_{e}$ are the initial and equilibrium concentration of BM at time t $(\mathrm{mg} / \mathrm{L})$ respectively.

$V$ is the volume of the solution contacted with the adsorbent (L).

$M$ is mass of the adsorbent (g).

All the experiments were done in triplicate and average values have been reported.

\section{Results and discussion}

\subsection{Ampelodesmos mauritanicus stems activated carbon characterisation}

The AMSAC prepared on the condition mentioned above was produced with a final yield of 37.54 wt. \%, which is a similar yield value to those reported previously by other authors [18-20]. In view of the data in Table 1, AMSAC shows high content of moisture (9.63\%), low percentage of volatile matter $(30.5 \%)$, average bulk density $(0.255 \mathrm{~g} / \mathrm{mL})$, high content of fixed carbon $(54.15 \%)$ and low ash content $(6.72 \%)$.

Furthermore, the impregnation stems with $\mathrm{H}_{3} \mathrm{PO}_{4}$ followed by a thermal treatment under nitrogen gas creates cavities on the surface of the activated carbon and increase its porosity and specific surface area due to the evaporation of activating agents during carbonization [21-24]. The BET surface area results indicated that AMSAC has surface area of $1293 \mathrm{~m}^{2} / \mathrm{g}$. This value is higher than that reported by Lim et al. [26] who showed that the surface area of $1109 \mathrm{~m}^{2} / \mathrm{g}$ from palm shells. Also, the surface area

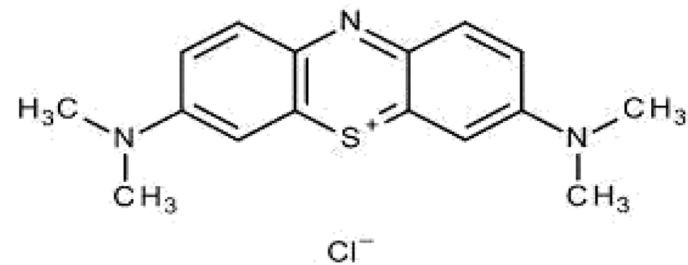

Fig. 2. Chemical Structure of Methylene bleu (MB) 
Table 1. Characterization of AMSAC prepared by phosphoric acid

\begin{tabular}{|l|c|}
\hline \multicolumn{1}{|c|}{ Parameter } & Value \\
\hline Bulk density $(\mathrm{g} / \mathrm{ml})$ & 0.255 \\
\hline Ash content $(\%)$ & 6.72 \\
\hline Moisture $(\%)$ & 9.63 \\
\hline Volatile matter $(\%)$ & 30.5 \\
\hline Yield $(\%)$ & 37.54 \\
\hline Iodine number $(\mathrm{mg} / \mathrm{g})$ & 1043 \\
\hline Methylene bleu number $(\mathrm{mg} / \mathrm{g})$ & 411.8 \\
\hline$S_{B E T}\left(\mathrm{~m}^{2} / \mathrm{g}\right)$ & 1293 \\
\hline Pore specific surface $\left(\mathrm{m}^{2} / \mathrm{g}\right)$ & 165.7 \\
\hline Total pore volume $\left(\mathrm{cm}^{3} / \mathrm{g}\right)$ & 1.23 \\
\hline Micropore volume $\left(\mathrm{cm}^{3} / \mathrm{g}\right)$ & 1.17 \\
\hline Average Pore diameter $(\mathrm{nm})$ & 1.93 \\
\hline
\end{tabular}

in this study is higher than reported by Liu et al. [27] who prepared activated carbon with surface area of $1179 \mathrm{~m}^{2} / \mathrm{g}$ from lotus stalks by $\mathrm{H}_{3} \mathrm{PO}_{4}$ activation. The prepared activated carbon in this study has pore surface area, pore diameter, pore volume and miropore volume of $165.7 \mathrm{~m}^{2} / \mathrm{g}, 1.93 \mathrm{~nm}, 1.23 \mathrm{~m} / \mathrm{g}$ and $1.17 \mathrm{~m}^{3} / \mathrm{g}$ respectively. In addition, the iodine adsorption number $(1043 \mathrm{mg} / \mathrm{g})$ and MB adsorption number $(411.8 \mathrm{mg} / \mathrm{g})$ measurements showed that the AMSAC was able to absorb small and large molecules equally well, suggesting the existence of high microporous structure.

The analysis of the nitrogen adsorption onto the product activated carbon is shown in Fig. 3. Here the quantity of $N_{2}$ adsorbed is plotted against the relative pressure $P / P_{0}\left(P\right.$ pressure, $P_{0}$ saturated vapor pressure) of $N_{2}$. It can be seen that the $\mathrm{N}_{2}$ adsorption isotherm of sample corresponds to type II curve according to the IUPAC classification [28], exhibiting a characteristic of microporous and mesoporous adsorbents.

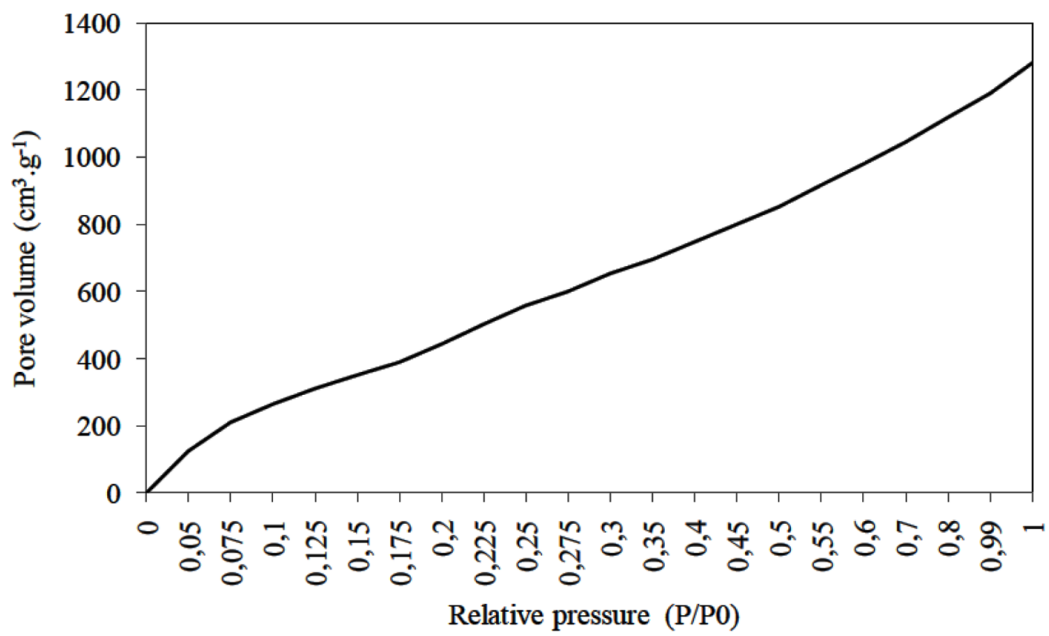

Fig. 3. Nitrogen sorption isotherm of AMSAC 
The BJH pore size distribution of AMSAC plotted in Fig. 4 was shown a wide distributions ranging from micro- to mesopores. Three peaks are observed in the micropore range $(<2 \mathrm{~nm})$ at pore widths of $0.9,1.4$ and $1.9 \mathrm{~nm}$. The result detected the strongest peak at pore width $0.9 \mathrm{~nm}$, showing a vast majority of the pores fall within the range of micropore structures.

The SEM images in Fig. 5 show the surface morphologies of AMSAC under two magnifications of $77 \mathrm{x}$ and $1138 \mathrm{x}$. It can be found that AMSAC has irregular fully solid structure with a porous and cavity distribution on its surface. The structure of more pores sizes formed can result from evaporation and breakdown of the non-carbon compounds contained in the stem of the Ampelodesmos mauritanicus. Large and well-developed pores were clearly found on the surface of the activated carbon. The presence of the activator can enlarge the pores of activated carbon and expand his surface [29].

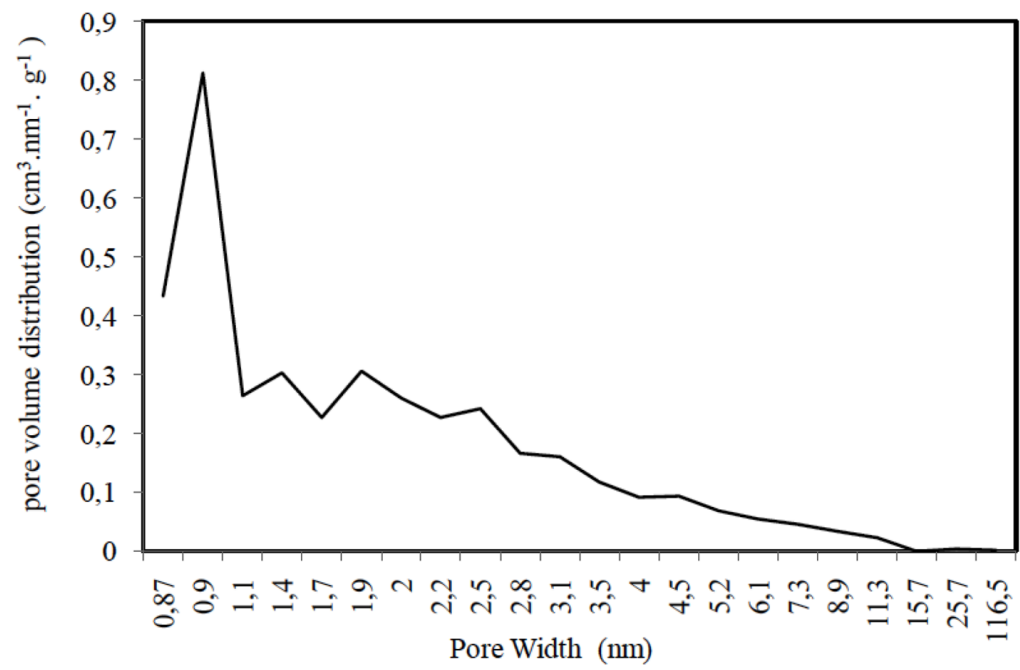

Fig. 4. Pore size distribution of AMSAC

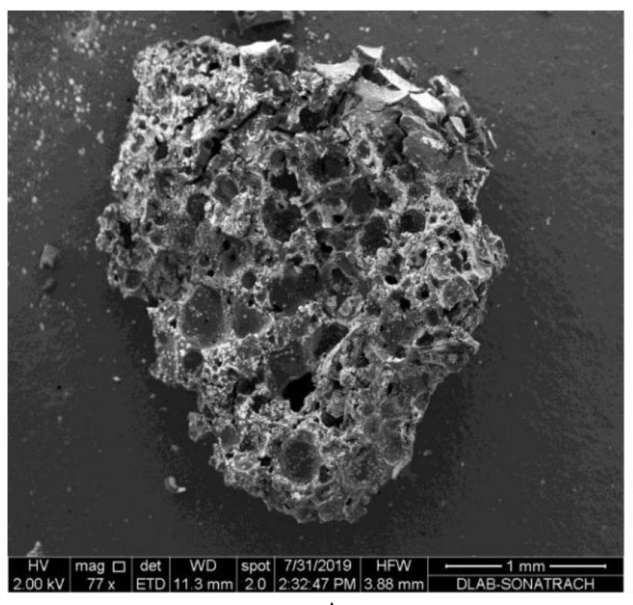

A

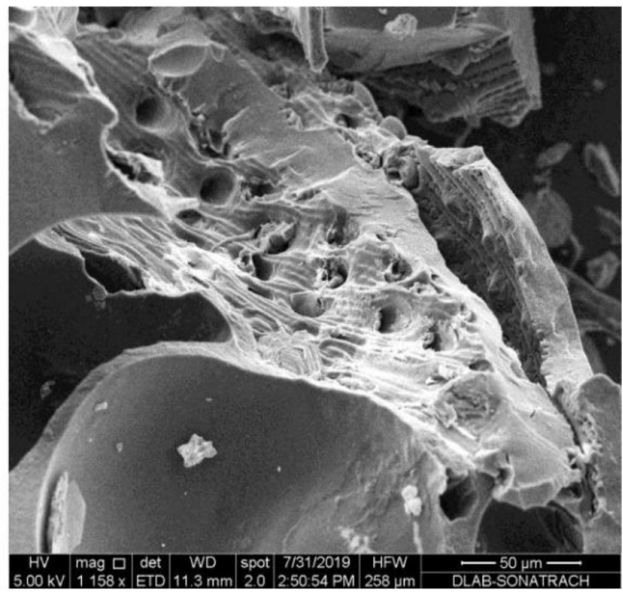

$\mathrm{B}$

Fig. 5. The SEM micrograph of AMSAC $(\mathrm{A}=77 \mathrm{x}$ and $\mathrm{B}=1138 \mathrm{x})$ 
Figure 6 shows the XRD pattern of AMSAC sample. This activated carbon which exhibit broad diffraction peaks and the absence of a sharp peak reveals a predominantly amorphous structure [16]. There are two centered broad diffraction peaks around $2 \theta=23^{\circ}$ and $44^{\circ}$ in spectrum, corresponding to the diffraction of (002) and (100), respectively. The appearance of the peak at around $23^{\circ}$ at activation temperature $\left(500{ }^{\circ} \mathrm{C}\right)$ signifies an increasing regularity of crystalline structure, which will result in a better layer alignmen. The crystallinity recorded by AMSAC is $7.2 \%$ with $92.8 \%$ amorphous. These results were closed to previous study which used different lignocellulosic raw materials $[30,31]$.

IR spectra of AMSAC (Fig. 7) show multiple functionality which can also be observed in other carbons obtained by phosphoric acid activation of lignocellulosic materials. The broad absorption

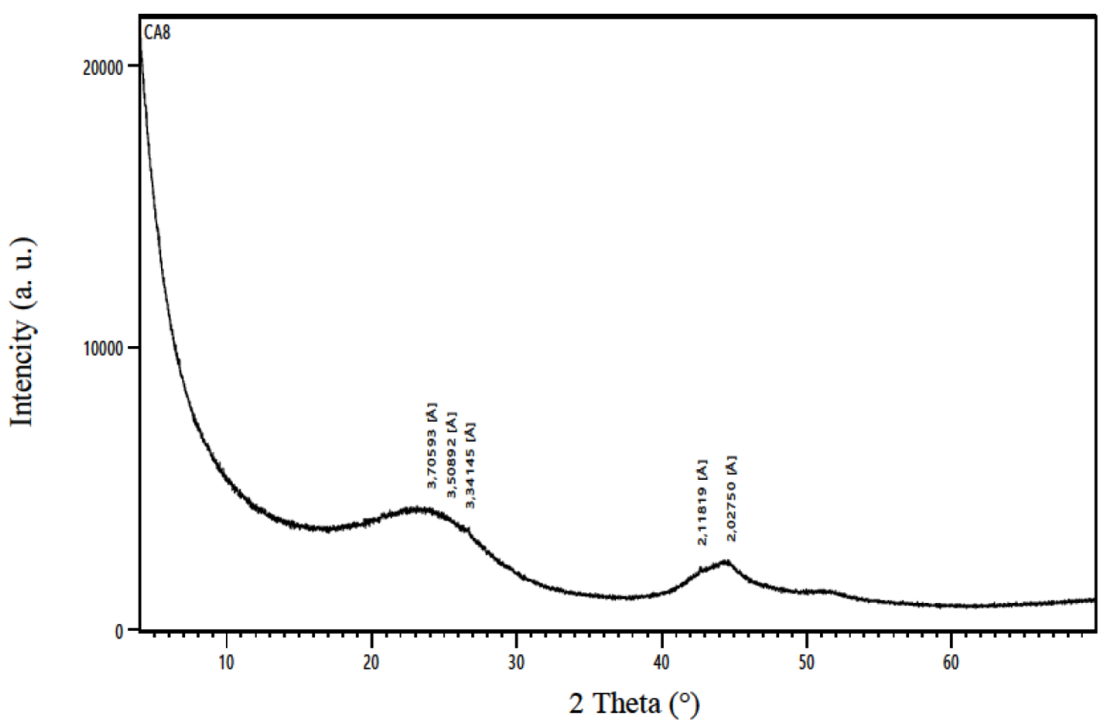

Fig. 6. X-ray diffraction pattern of AMSAC sample

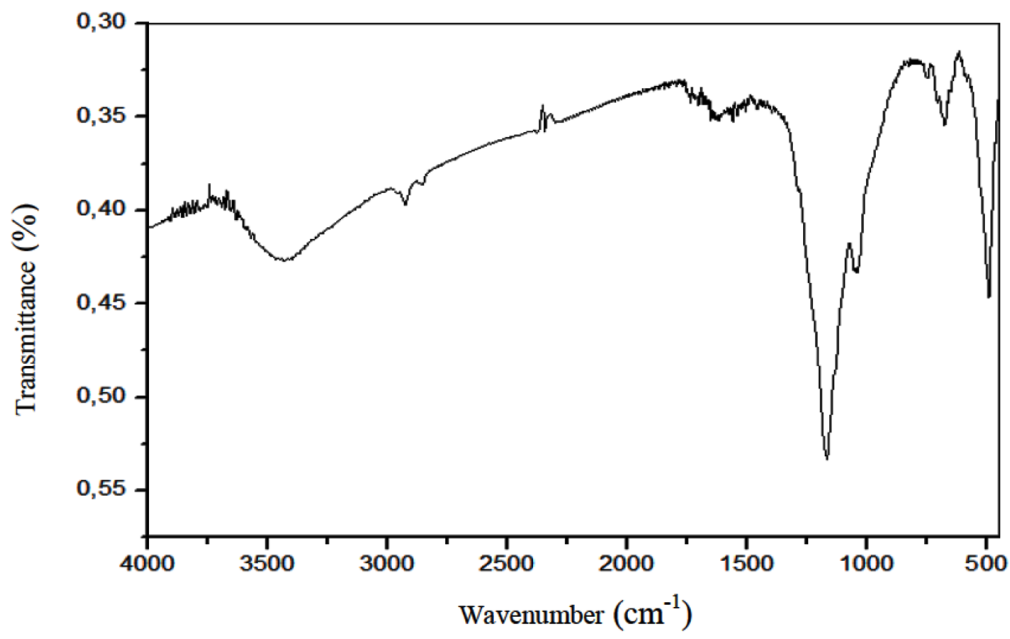

Fig. 7. FTIR spectra of AMSAC 
band at $3700-3100 \mathrm{~cm}^{-1}$ with a maximum at about $3400-3340 \mathrm{~cm}^{-1}$ is characteristic of the stretching vibration of hydrogen-bonded hydroxyl of phenolic groups. The band at $2800-3000 \mathrm{~cm}^{-1}$ indicates the presence of an aliphatic $\mathrm{C}-\mathrm{H}$. The spectra shows a small peak at $1695-1710 \mathrm{~cm}^{-1}$, according to MontesMorán et al. [32], that can be assigned to the $\mathrm{C}=\mathrm{C}$ symmetrical stretching of pyrone groups and $\mathrm{C}=\mathrm{O}$ of carboxylic groups. The band at $1000-1300 \mathrm{~cm}^{-1}$ is usually found with oxidized carbons and has been assigned to $\mathrm{C}-\mathrm{O}$ stretching in acids, alcohols, phenols, ethers, and/or esters groups. Nevertheless, it is also characteristic of phosphorus and phosphor-carbonaceous compounds present in $\mathrm{H}_{3} \mathrm{PO}_{4}$ activated carbons. The band at $1080-1065 \mathrm{~cm}^{-1}$ could be due to $\mathrm{P}^{+}-\mathrm{O}^{-}$in acid phosphate esters and to the symmetrical vibration in polyphosphate chain P-O-P [33]. In addition, the vibration bands located at $1026 \mathrm{~cm}^{-1}$ can be ascribed to stretching modes of $\mathrm{Si}-\mathrm{O}-\mathrm{Si}$, representing the existence of silicate functional groups [34].

\subsection{Adsorption isotherm}

The equilibrium data were fitted to the Langmuir and Freundlich isotherm models which were expressed by Langmuir equation (Eq. (2)) and Freundlich equation (Eq. (2)).

$$
\begin{aligned}
& C_{e} / q_{e}=1 /\left(K_{L} q_{0}\right)+\left(1 / q_{0}\right) C_{e}, \\
& \log q e=\log k_{F}+(1 / n) \log C e,
\end{aligned}
$$

Where:

$q_{e}$ is the mass of MB are adsorbed on adsorbent at equilibrium (mg/g).

$q_{0}$ is the maximum adsorption capacity $(\mathrm{mg} / \mathrm{g})$.

$K_{L}$ is a Langmuir constant $(\mathrm{L} / \mathrm{mg})$ related to the energy of adsorption.

$K_{F}$ is the Freundlich constant $(\mathrm{L} / \mathrm{g})$ related to the bonding energy.

$1 / n$ is the heterogeneity factor in which $n$ is a measure of the deviation from linearity of the adsorption.

The essential characteristic of the Langmuir isotherm may be expressed in terms of dimensionless separation parameter $R_{L}$, which is indicative of the isotherm shape that predicts whether an adsorption system is unfavourable if $R_{L}>1$ ), linear if $R_{L}=1$, favourable if $0<R_{L} . R_{L}$ is defined as:

$$
R_{L}=1 /\left(1+\left(1+K_{L} / C_{0}\right)\right)
$$

Were:

$C_{0}$ is initial concentration of the adsorbent $(\mathrm{mg} / \mathrm{L})$.

In this analysis, correlation coefficient $\left(R^{2}\right)$ and nonlinear chi-square test $\left(\chi^{2}\right)$ were used for the determination of best-fitting isotherm with the experimental data. The mathematical derivation was given by the Eq. (5):

$$
\chi^{2}=\left(\sum\left(q_{e}-q_{c a l}\right)^{2} / q_{e}\right),
$$

Where:

$q_{c a l}$ is the equilibrium capacity $(\mathrm{mg} / \mathrm{g})$ calculated from model.

$\chi^{2}$ would be a small number and vice versa when the data from model are similar to the experimental data. 
The plots were presented in Figs. 8 and 9 and the relative parameters were listed in Table 2. For the Langmuir model, $C e$ vs. Ce/qe were plotted (Fig. 8) used to calculate $q_{m}$ which was $400.6 \mathrm{mg} / \mathrm{g}$. With a calculated $q_{m}(400.6 \mathrm{mg} / \mathrm{g})$ that almost matches the experimental $(411.8 \mathrm{mg} / \mathrm{g})$ with nonlinear Chi-square test $\left(\chi^{2}\right) 0.167$ and an $\mathrm{R}^{2}$ value of 0.997 , Langmuir model describes the adsorption behavior well. For the Freundlich model, $\log (C e)$ vs $\log (q e)$ were drawn (Fig. 9) and the best fit was used to find the slope and intercept. The Freundlich constant, $K_{F}$, and exponent, $n$, were calculated and listed in Table 2 along with the Langmuir parameters. Between the two models, the Freundlich model showed less variance $\left(R^{2}=0.975\right)$; then, it does not describes well the behavior of MB adsorption on AMSAC. Since the Langmuir model is more suitable to describe the experimental data, this suggests that the sorbent surface has uniformly distributed homogenous surface adsorption sites available for MB. It also assumes that during adsorption the energy is uniformly distributed between the adsorbate surface and adsorbent molecules for monolayer adsorption regardless of the $\mathrm{pH}$ and the temperature effect. The

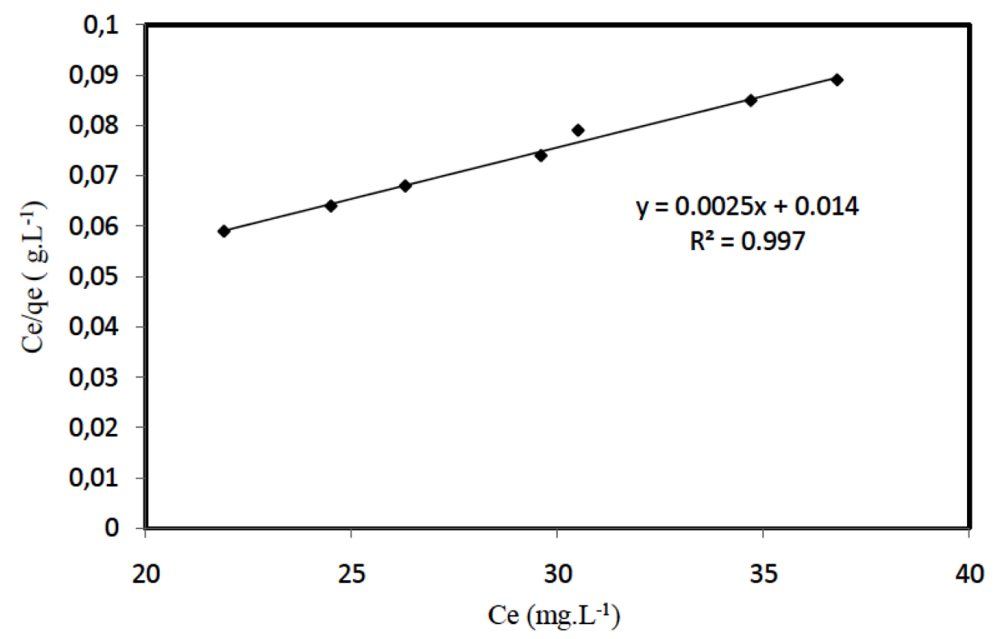

Fig. 8. The plot of Langmuir adsorption isotherm

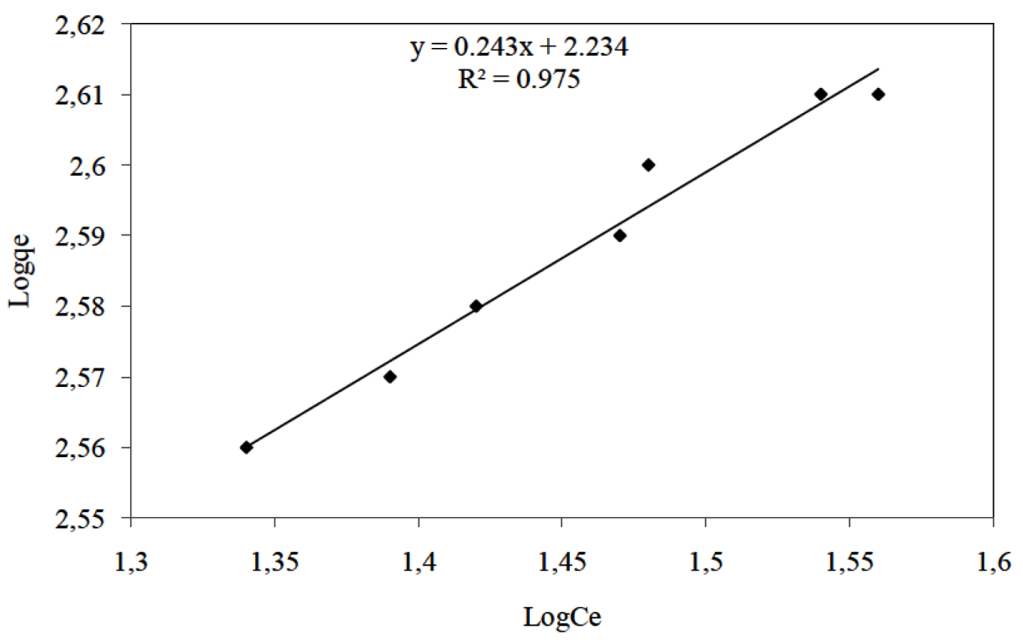

Fig. 9. The plot of Freudlich adsorption isotherm 
Table 2. Isotherm constant for the adsorption of MB ions onto AMSAC

\begin{tabular}{|c|c|c|c|c|}
\hline Isotherm & Equation & Parameter & Value & $\mathrm{X}_{\mathrm{t}}^{2}$ \\
\hline \multirow[t]{4}{*}{ Langmiur } & $\begin{array}{c}\mathrm{C}_{\mathrm{e}} / \mathrm{q}_{\mathrm{e}}=1 /\left(\mathrm{K}_{\mathrm{L}} \mathrm{q}_{\mathrm{m}}\right)+ \\
\mathrm{C}_{\mathrm{e}} / \mathrm{q}_{\mathrm{m}}\end{array}$ & $\mathrm{R}^{2}$ & 0.997 & 0.167 \\
\hline & $\mathrm{R}_{\mathrm{L}}=1 /\left(1+\mathrm{K}_{\mathrm{L}} \mathrm{C}_{0}\right)$ & $q_{m}(\mathrm{mg} / \mathrm{g})$ & 400.6 & \\
\hline & & $K_{L}(\mathrm{~L} / \mathrm{mg})$ & 0.143 & \\
\hline & & $\mathrm{R}_{\mathrm{L}}$ & 0.499 & \\
\hline \multirow[t]{3}{*}{ Freundlich } & $\begin{aligned} \log q_{e}= & \log K_{F}+(1 / n) \\
& \log C e\end{aligned}$ & $\mathrm{R}^{2}$ & 0.975 & 5.119 \\
\hline & & $\mathrm{K}_{\mathrm{f}}(\mathrm{L} / \mathrm{mg})$ & 171.4 & \\
\hline & & $\mathrm{n}$ & 4.11 & \\
\hline
\end{tabular}

Table 3. Comparison of maximum adsorption capacity of MB by different adsorbents

\begin{tabular}{ccc}
\hline Adsorbent & $\mathrm{q}_{\mathrm{m}}(\mathrm{mg} / \mathrm{g})$ & Reference \\
\hline Posidonia oceanica dead leaves & 285.7 & {$[35]$} \\
Cotton stalk & 193.5 & {$[36]$} \\
Date stones & 316.1 & {$[37]$} \\
Cashew nut shell & 68.7 & {$[38]$} \\
Vetiver roots & 423.0 & {$[39]$} \\
Durian shell & 289.3 & {$[40]$} \\
Activated charcoal & 342.7 & {$[41]$} \\
Commercial activated carbon & 930.33 & {$[42]$} \\
This work & 411.8 &
\end{tabular}

sorption capacity of the AMSAC obtained in this study can be regarded as relatively high and could be compared to other materials reported in the literature (Table 3).

Also, according to the data represented in Table 2, the favorable Langmuir isotherm is observed for $R_{L}$ (the separation factor) values greater than 0 and lesser than 1 . The low values of $R_{L}=0.499$ indicate high and favorable adsorption of MB onto AMSAC [43].

\section{Conclusion}

Ampelodesmos mauritanicus stems were chemically activated with the well-established conditions of ortho-phosphoric acid $\mathrm{H}_{3} \mathrm{PO}_{4}$ solutions (85\%) in weight ration $1: 2 \mathrm{~g} / \mathrm{g}$ and activation temperature $500{ }^{\circ} \mathrm{C}$. Derived carbons indicate high quality adsorbents with surface areas of $1292 \mathrm{~m}^{2} / \mathrm{g}$ and total pore volumes of $1,23 \mathrm{~cm}^{2} / \mathrm{g}$, which are essentially microporous and mesoporous. Methylene blue was selected as a model dye in order to evaluate the capacity of the AMSAC remove dyes from aqueous solutions. The isotherms study showed that Langmuir isotherm model fitted well with the experimental equilibrium data with the maximum monolayer adsorption of $411.8 \mathrm{mg} / \mathrm{g}$ for MB. This new AC provides very promising results for cost-effective treatment of wastewaters contaminated by cationic dyes, as it is easy to prepare and is derived from a widely available, low-cost biomass feedstock. 


\section{Acknowledgments}

The authors wish to thank M'Hamed Bougara University and research center of SONATRACH at Boumerdes for their technical support during the course of work.

\section{References}

1. Cagnon B., Xavier P., Guillot A., Stoeckli F., Chambat G. Contributions of hemicelluloses, cellulose and lignin to the mass and the porous properties of chars and steam activated carbons from various lignocellulosic precursors. Bioresource Technology 2008. V. 100 (1), P. 292-298. https://doi. org/10.1016/j.biortech.2008.06.009

2. Ioannidou O., Zabaniotou A. Agricultural residues as precursors for activated carbon production-A review. Renewable and Sustainable Energy 2007. 11(9), P. 1966-2005. https://doi. org/10.1016/j.rser.2006.03.013

3. Yates M., Blanco J., Avila P., Martin M.P. Honeycomb monoliths of activated carbons for effluent gas purification. Microporous and Mesoporous Material 2000. V. 37(1-2), P. 201-208. https:// doi.org/10.1016/s1387-1811(99)00266-8

4. Nahil M.A., Williams P.T. Pore characteristics of activated carbons from the phosphoric acid chemical activation of cotton stalks. Biomass and Bioenergy 2012. V. 37, P. 142-149. https://doi. org/10.1016/j.biombioe.2011.12.019

5. Dula T., Siraj K., Kitte S.A. Adsorption of chromium from aqueous solution using chemically activated carbon prepared from locally available waste of bamboo. ISRN Environmental Chemistry 2014. V. 11, P. 1-6. https://doi.org/10.1155/2014/438245

6. Chowdhury Z.Z., Zain S.M., Khan R.A., Islam S. Preparation and characterizations of activated carbon from kenaf fiber for equilibrium adsorption studies of copper from wastewater. J. Applied Sciences Engineering and Technology 2012. V. 29(9), P. 1187-1195. https://doi.org/10.1016/j. proche.2016.03.053

7. Girgis B.S., Khalil L.B., Tawfik T.A.M. Activated carbon from sugar cane bagasse by carbonization in the presence of inorganic acids. Journal of chemical technology and biotechnology 1994. V. 61(1), P. 87-92. https://doi.org/10.1002/jctb.280610113

8. Dang V.B.H., Doan H.D., Dang-Vu T., Lohi A. Equilibrium and kinetics of biosorption of cadmium(II) and copper(II) ions by wheat straw. Bioresource Technology 2009. V. 100 (1), P. 211-219. https://doi.org/10.1016/j.biortech.2008.05.031

9. Jain M., Garg V.K., Kadirvelu K. Chromium(VI) removal from aqueous system using helianthus annus (sunflower) stem waste. Journal of Hazardous Materials 2009. V. 162(1), P. 365-372. https://doi.org/10.1016/j.jhazmat.2008.05.048

10. Faraoun F., Bouzidi M.A., Attaoui I., Latreche A., Meliani H., Benyahia M. Caractérisation des formations végétales à Ampelodesmos mauritanicus sur Djebel Tessala, Algérie occidentale. Afrique SCIENCE 2016. V. 12(5), 326-335.

11. Zerganea H., Abdia S., Xub H., Hemming J., Wang X., Willför S., Habibid Y. Ampelodesmos mauritanicus a new sustainable source for nanocellulose substrates. Industrial Crops and Products 2020. V. 144, P. 112044. https://doi.org/10.1016/j.indcrop.2019.112044

12. Luzia F., Pugliaa D., Sarasinib F., Tirillòb J., Maffeib G., Zuorrob A., Lavecchiab R., Kennya J.M., Torrea L. Valorization and extraction of cellulose nanocrystals from North African 
grass: Ampelodesmos Mauritanicus. Carbohydrate Polymers 2019. V. 209, P. 328-337. https://doi. org/10.1016/j.carbpol.2019.01.048

13. Bourahli M.E.H., Osmani H., Nat J. Chemical and mechanical properties of diss (Ampelodesmos mauritanicus). Fibers 2013. V. 10, P. 219-232. https://doi.org/10.1080/15440478.2012.761115

14. Puziy A.M., Poddubnay O.I., Martínez-Alonso A., Suárez-García F. Surface chemistry of phosphorus containing carbons of lignocellulosic origin. Carbon 2005. V. 43, P. 2857-2868. https://doi. org/10.1016/j.carbon.2005.06.014

15. Yoshiguk, S., Yukata K. Pyrolysis of plant, animal and human waste: physical and chemical characterization of the pyrolytic products. Bioresource Technology 2003. V. 90(3), P. 241-247. https:// doi.org/10.1016/S0960-8524(03)00147-0

16. Rodríguez-Mirasol J., Cordero T., Rodríguez J.J. Preparation and characterization of activated carbons from eucalyptus kraft lignin. Carbon 1993. V. 31(1), P. 87-95. https://doi.org/10.1016/00086223(93)90160-C

17. Sych N.V., Trofymenko S.I., Poddubnaya O.I., Tsyba M.M., Sapsay V.I., Klymchuk D.O., Puzity A.M. Porous structure and surface chemistry of phosphoric acid activated carbon from corncob. Applied surface science 2012. V. 261, P. 75-82. https://doi.org/10.1016/j.apsusc.2012.07.084

18. Zhu G.Z., Deng X.L., Hou M., Sun K., Zhang Y.P., Li P. Comparative study on characterization and adsorption properties of activated carbons by phosphoric acid activation from corncob and its acid and alkaline hydrolysis residues. Fuel Process. Technol. 2016. V. 144, P. 255-261. https://doi. org/10.1016/j.fuproc.2016.01.007

19. Standard test method for total ash content of activated carbon (ASTM-D2866-94), American Society for Testing and Materials, Philadelphia, 1995.

20. Bestani B., Benderdouche N., Bensttali B., Mostefa B., Addou A. Methylene blue and iodine adsorption onto an activated desert plant. Bioresource Technology 2008. V. 99(17), P. 8441-8444. https://doi.org/10.1016/j.biortech.2008.02.053

21. EL Aboudia I., Annaba H., Mdarhria A., Amjouda M., Servantc L. Activated carbon synthesis using Moroccan dates stones as precursor and application for wastewater treatment. Journal of Materials and Environmental Sciences 2017. V. 8(4), P. 1483-1481.

22. Nahil M.A., Wiliams P.T. Pore characteristics of activated carbons from the phosphoric acid chemical activation of cotton stalks. Biomass and bioenergy 2012. V. 37, P. 142-149. https://doi. org/10.1016/j.biombioe.2011.12.019

23. Guo J., Lua A.C. Textural and chemical properties of adsorbent prepared from palm shell by phosphoric acid activation. Materials Chemistry and Physics 2003. V. 80, P. 114-119. https://doi. org/10.1016/S0254-0584(02)00383-8

24. Hong B., Xue G., Weng L., Guo, X. Pretreatment of moso bamboo with dilute phosphoric acid. Bioresources 2012. V. 7(4), P. 4902-4913.

25. Thanapal S.S., Chen W., Annamalai K., Carlin N., Ansley R.J., Ranjan D. Carbon Dioxide Torrefaction of Woody Biomass. Energy \& Fuels 2014. V. 28(2), P. 1147-1157. https://doi.org/10.1021/ ef4022625

26. Lim W.C., Srinivasakannan C., Balasubramanian N. Activation of palm shells byphosphoric acid impregnation for high yielding activated carbon. J. Anal. Appl.Pyrolysis 2010. V. 88, P. 181-186. https://doi.org/10.1016/j.jaap.2010.04.004 
27. Liu H., Zhang J., Zhang C., Bao N., Cheng C. Activated carbons with well-developed microporosity and high surface acidity prepared from lotus stalks by organophosphorus compounds activations. Carbon 2013. V. 60, P. 289-291. https://doi.org/10.1016/j.carbon.2013.04.039

28. Jagtoyen M., Derbyshire F. Activated carbons from yellow poplar and white oak by $\mathrm{H}_{3} \mathrm{PO}_{4}$ activation. Carbon 1998. V. 36 (7-8), P. 1085-1094. https://doi.org/10.1016/S0008-6223(98)00082-7

29. Schrodter K., Bettermann G., Staffel T., Hofman T. Ullmann's Encyclopedia of Industrial Chemistry, vol. A19, VCH, Weinheim, 1991.

30. Babar A.A., Panhwar I., Qureshi S., Memon S., Siddiqui Z. Utilization of Biomass (Rice Straw) to Produce Activated Charcoal Through Single Stage Pyrolysis Process. Journal of international environmental application \& Science 2019. V. 14(1), P. 1-6.

31. Serrano V.G., Villegas J.P., Florindo A.P., Valle C.D., Calahorro C.V. Calahorro, FT-IR study of rockrose and of char and activated carbon. J. Anal. Appl. Pyrol. 1996. V. 36, P. 71-80. https://doi. org/10.1016/j.apsusc.2012.11.164

32. Figueiredo J.L., Pereira M.F.R., Freitas M.M.A., Órfão J.J.M. Modefication of the surface chemistry of activated carbones. Carbon 1999. V. 37, P. 1379-1389. https://doi.org/10.1016/S00086223(98)00333-9

33. Prahas D., Kartika Y., Indraswati N., Ismadji S. Activated carbon from jackfruit peel waste by $\mathrm{H}_{3} \mathrm{PO}_{4}$ chemical activation: Pore structure and surface chemistry characterization. Chemical Engineering Journal 2008. V. 140, P. 32-42. https://doi.org/10.1016/j.cej.2007.08.032

34. Saurabh C.K., Mustapha A., Masri M.M., Owolabi A., Syakir M., Dungani R., Paridah M., Jawaid M., Abdul Khalil H. Isolation and characterization of cellulose nanofibers from Gigantochloa scortechinii as a reinforcement material. J. Nanomater 2016. V. 172, P. 234-242. https://doi. org/10.1155/2016/4024527

35. Dural M.U., Cavas L., Papageorgiou S.K., Katsaros F.K. Methylene blue adsorption on activated carbon prepared from posidonia oceanic (L) dead leaves: Kinetics and equilibrium studies. Chemical Engineering Journal 2011. V. 168(1), P. 77-85. https://doi.org/10.1016/j.cej.2010.12.038

36. Deng H., Yang L., Tao G., Dai J. Preparation and characterization of activated carbon from cotton stalk by microwave assisted chemical activation: application in methylene blue adsorption from aqueous solution. Journal of Hazardous Materials 2009. V. 166 (2-3), P. 1514-1521. https://doi. org/10.1016/j.jhazmat.2008.12.080

37. Foo K., Hameed B. Preparation of activated carbon from date stones by microwave induced chemical activation: application for methylene blue adsorption. Chemical Enginneering Journal 2011. V. 170(1), P. 338-341. https://doi.org/10.1016/j.cej.2011.02.068

38. Kumar P.S., Ramalingam S., Sathishkumar K. Removal of methylene blue dye from aqueous solution by activated carbon prepared from cashew nut shell as a new low-cost adsorbent. Korean Journal of chemical engineering 2010. V. 28(1), P. 149-155. https://doi.org/10.1007/s11814-010-0342-0

39. Altenor S., Carene B., Emmanuel E., Lambert J., Ehrhardt J.J., Gaspard S. Adsorption studies of methylene blue and phenol onto vetiver roots activated carbon prepared by chemical activation. Journal hazardous materials 2009. V. 165(1-3), P. 1029-1039. https://doi.org/10.1016/j.jhazmat.2008.10.133

40. Chandra T.C., Mirna M.M., Sudaryanto Y., Ismadji S. Adsorption of basic dye onto activated carbon prepared from durian shell: Studies of adsorption equilibrium and kinetics. Chemical Engineering Journal 2007. V. 127(1-3), P. 121-129. https://doi.org/10.1016/j.cej.2006.09.011 
41. Iqbal M.J., Ashiq M.N. Adsorption of dyes from aqueous solutions on activated charcoal. Journal of hazardous Material 2007. V. 139(1), P. 57-66. https://dio.org/10.1016/j.jhazmat.2006.06.007

42. Kannan N., Sundaram M.M. Kinetics and mechanism of removal of methylene blue by adsorption on various carbons-a comparative study. Dyes and Pigments 2001. V. 51(1), P. 25-40. https://doi.org/10.1016/S0143-7208(01)00056-0

43. Weber T.W., Chakraborti R.K. Pore and solid diffusion models for fixed bed adsorbers. AIChE Journal 1974. V. 20 (2), P. 228-238. https://doi.org/10.1002/aic.690200204 